Dariusz WIĘCEK ${ }^{1}$, Łukasz BYRDY²

Opiekun naukowy: Józef MATUSZEK ${ }^{3}$

DOI: https://doi.org/10.53052/9788366249844.25

\title{
OCENA TECHNOLOGICZNOŚCI KONSTRUKCJI Z PUNKTU WIDZENIA CZASU I KOSZTÓW PROCESÓW MONTAŻU
}

Streszczenie: W opracowaniu wyjaśniono pojęcie technologiczności konstrukcji, i jej znaczenie z punktu widzenia wytwarzania wyrobów. Podano zasady konstrukcyjnego przygotowania produkcji z punktu widzenie technologiczności konstrukcji wytwarzanych elementów. Podano metodykę postępowania w ocenie technologiczności konstrukcji wyrobu.

Słowa kluczowe: procesy montażu, produkcja jednostkowa i małoseryjna, czas i koszty montażu

\section{ASSESSMENT OF THE TECHNOLOGY OF THE CONSTRUCTION FROM THE POINT OF VIEW OF THE TIME AND COSTS OF THE ASSEMBLY PROCESSES}

Summary: The study explains the concept of the technological efficiency of the structure and its meaning from the point of view of the manufacturing of products. Given are the principles of the constructional preparation of production from the point of view of the technological design of the manufactured elements. The methodology of proceeding in the assessment of the technological efficiency of the product structure was given.

Keywords: assembly process, unit and small-lot production, time and cost of production

\section{Udział prac montażowych w procesach produkcyjnych wyrobów}

Współczesne procesy produkcji charakteryzują się postępującym stopniem automatyzacji, wytwarzaniem wyrobów dostosowanych do indywidualnych potrzeb klienta, zwiększeniem seryjności wytwarzania komponentów wchodzących w skład

${ }^{1}$ dr inż., Akademia Techniczno - Humanistyczna w Bielsku - Białej, Wydział Budowy Maszyn i Informatyki,wiecekd@ath.bielsko.pl

${ }^{2}$ mgr inż., Akademia Techniczno - Humanistyczna w Bielsku - Białej, Wydział Budowy Maszyn i Informatyki, lbyrdy@ath.bielsko.pl

${ }^{3}$ prof. dr hab. inż., Akademia Techniczno - Humanistyczna w Bielsku - Białej, Wydział Budowy Maszyn i Informatyki, jmatuszek@ath.bielsko.pl 
tych wyrobów przez wprowadzenie unifikacji i normalizacji ich konstrukcji [11]. Ponadto rozwój technologii obróbki (na drodze automatyzacji i zwiększeniu możliwości wykonania złożonych postaci konstrukcyjnych obrabianych przedmiotów) przy ciągle jeszcze znacznym udziale prac ręcznych w procesach montażu wyrobów gotowych, spowodowały potrzebę nowego podejścia do wdrażania do produkcji nowych wyrobów [8].

Prace związane montażem w całym procesie produkcyjnym stanowią istotny udział w czasach i kosztach produkcji wyrobów. [3]. W przypadku produkcji jednostkowej i małoseryjnej ze względu na duży zakres prac ręcznych wkład ten jest jeszcze największy. Udział działań montażu w głównej mierze zależy od rodzaju konstrukcji, stopnia automatyzacji oraz doświadczenia i kwalifikacji pracowników $[6,7,8,9]$. Na etapie powstawania projektu wyrobu to w głównej mierze na konstruktorze ciąży odpowiedzialność za cechy projektowanego wyróbu, które wpływają na kształtowanie procesu produkcyjnego, a co za tym idzie na jego walory użytkowe oraz niezawodność pracy. Nieprawidłowo zaprojektowany proces może skutkować powstaniem nieprzewidzianych kosztów, które przedsiębiorstwo będzie musiało ponieść $\mathrm{w}$ trakcie procesów wytwarzania i serwisowania. Jednym z podstawowych zadań projektanta jest dążenie do maksymalizacji liczby elementów zunifikowanych w opracowywanym projekcie wyrobu, a ogólna liczba elementów w konstrukcji była zminimalizowana. Struktura montażowa wyrobu powinna być zaprojektowana w taki sposób, aby pozycje współpracujących elementów były jednoznacznie określone, co powinno zapobiec błędom podczas procesu montażu [12].

\section{Technologiczność konstrukcji}

\subsection{Pojęcie technologiczności konstrukcji}

Rozwój nowego produktu od powstania koncepcji do wprowadzenia go na rynek jest złożony oraz zdeterminowany przez różne kryteria użyteczności [5]. Proces ten wymaga szeregu działań, które uzależnione są od rodzaju i złożoności wyrobów, seryjności produkcji oraz przygotowania organizacyjno-techinczego. Największą uwagę należy zwrócic na projektowanie procesów obróbki oraz montażu, a szczególnie określić działania wytwórcze jakie należy wykonać oraz w jakiej kolejności mają następować po sobie.

Poprzez technologiczność konstrukcji można rozumieć cechy produktu za pomoca których możliwe staje się uzyskanie wymaganych właściwości wyrobu przy jednoczesnej minimalizacji kosztów wytwarzania dla określonej wielkości i warunków produkcyjnych [1]. Jeżeli weźmie się pod uwagę dwa wyroby o różnych konstrukcjach, które są całkowicie zgodne z założeniami, to bardziej technologiczna będzie ta, która została uzyskana przy mniejszym nakładzie czasów i kosztów produkcji [1].

Proces projektowania przebiegu montażu charakteryzuje się dużym naciskiem na technologiczność konstrukcji wyrobu.

Wymaganą technologiczność konstrukcji uzyskuje się przy ścisłej współpracy osób projektujących konstrukcję, procesy wytwarzania i organizacji produkcji począwszy od etapu opracowywania koncepcji wyrobu. Jeżeli takie podejście nie jest możliwe i technolog dostaje gotową dokumentację od konstruktora (np. przy wykorzystaniu 
konstruktorów zewnętrznych) to jego ocena technologiczności konstrukcji powinna polegać na sprawdzeniu [1]:

- normalizacji i unifikacji zespołów lub ich części,

- racjonalności doboru materiałów wyjściowych do produkcji,

- prawidłowości zaprojektowania części w celu sensownego kształtowania półfabrykatów,

- $\quad$ poprawności projektów części ze względu na proces obróbki,

- $\quad$ poprawności zaprojektowana części ze względu na ich montaż.

\subsection{Zasady technologiczności konstrukcji ze względu na montaż}

Montaż wyrobów polega na łączeniu jego składowych komponentów. Komponentami tymi mogą być zespoły, podzespoły, pojedyncze elementy. W pierwszej kolejności montowane są podzespoły, te $\mathrm{z}$ kolei w zespoły, w końcowym etapie następuje montaż ostateczny. Przykładową strukturę montażową wyrobu W przedstawiono na rys. 1 .

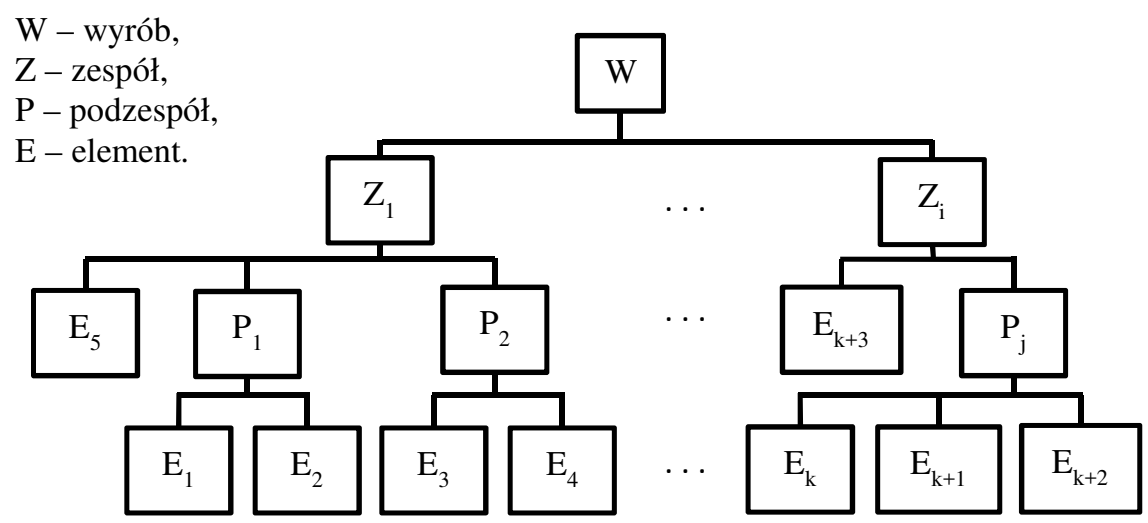

Rysunek 1. Przykładowy schemat montażu wyrobu W [źródło: opracowanie własne]

Montaż części można przeprowadzić na wiele różnych sposobów, które przedstawiono za pomocą wzorów algebraicznych (użyte we wzorach znaki $\mathrm{E}_{\mathrm{k}}$ oznaczają poszczególne części) [12]:

a) kolejny montaż (lub szeregowy) pojedynczych części

$$
E_{1}+E_{2}+E_{3}+E_{4}+E_{5}+\cdots+E_{k}
$$

b) montaż równoległy z podzespołów

$$
\left(E_{1}+E_{2}+E_{3}\right)+\left(E_{4}+E_{5}\right)+\left(E_{7}+E_{8}\right)+\cdots+\left(E_{k}+\right.
$$

c) montaż z podzespołów i pojedynczych części

$$
\left(E_{1}+E_{2}+E_{3}\right)+\left(E_{4}+E_{5}\right)+E_{6}+E_{7}+\cdots+E_{k},
$$

d) montaż z zespołów, podzespołów i pojedynczych części

$$
\begin{aligned}
& {\left[\left(E_{1}+E_{2}+E_{3}\right)+\left(E_{4}+E_{5}\right)\right]+\left(E_{6}+E_{7}\right)+E_{8}+E_{9}+} \\
& \cdots+E_{k}+E_{k+1},
\end{aligned}
$$

e) montaż z grup montażowych, zespołów, podzespołów i części 


$$
\begin{aligned}
& \left\{\left[\left(E_{1}+E_{2}\right)+\left(E_{2}+E_{3}\right)\right]+\left(E_{4}+E_{5}\right)\right\}+\left(E_{6}+E_{7}\right)+ \\
& E_{8}+E_{9}+\cdots+E_{k}+E_{k+1} .
\end{aligned}
$$

Sposób, w jaki części mają być montowane powinien znajdować się w karcie instrukcji montażu, w której powinny być zawarte takie informacje jak [12]:

- numer operacji i zabiegu montażowego,

- wykaz części użytych w danym zabiegu wraz z ich ilością,

- sposób łączenia elementów za pomocą schematu graficznego,

- treść zabiegu,

- wykaz potrzebnego oprzyrządowania,

- czasy robocze,

- zaszeregowanie pracy.

Z punktu widzenia procesów wytwarzania można rozróżnić następujące zasady technologiczności konstrukcji [1,2,10,12]:

- zasada zespołowości: zasada zespołowości polega na tworzeniu niezależnych zespołów oddzielnie montowanych, docieranych, kontrolowanych, a następnie montowanych. Wykorzystanie tej zasady umożliwia równoległy montaż zespołów wyrobu redukując całkowity czas montażu, a także ułatwia montaż końcowy. Ułatwiony jest również proces naprawy, gdyż możliwa staje się wymiana konkretnego zespołu, a nie całej maszyny.

- zasada unifikacji elementów konstrukcyjnych: za pomocą unifikacji elementów konstrukcyjnych można uzyskać krótsze czasy potrzebne do wyprodukowania wyrobu. Jest to bardzo istotne głównie w przypadku elementów, które wymagają dużych nakładów pracy oraz powtarzających się (np. koła zębate).

- zasada minimalizacji liczby części; zasada ta pozwala na eliminację elementów zbędnych w konstrukcji przez zastosowanie części lub zespołów spełniających kilka zadań.

- zasada baz montażowych: położenie elementów montowanych w projektowanym wyrobie powinno być ściśle i jednoznacznie określone przez bazy montażowe co ogranicza możliwość wystąpienia sytuacji, że pracownik zamontuje element błędnie. Bazowanie można wykonywać w kierunku osi, na powierzchniach walcowych oraz na powierzchniach płaskich.

- zasada samonastawności: poprzez wykorzystanie zasady samonastawności w przypadku połączeń ruchowych niezawodność użytkowania może być polepszona, a sam montaż ułatwiony. Mimo pewnych niedokładności wykonania i montażu elementów pozwala ona na zapewnienie prawidłowej pracy wyrobu.

- zasada eliminowania naprężeń powstających podczas montażu: dla nieprawidłowo zaprojektowanej konstrukcji pod wpływem naprężeń niektóre jej elementy mogą ulec odkształceniu przez co praca wyrobu będzie wadliwa. Należy dążyć do eliminacji przyczyn wywołujących powstawanie naprężeń.

- zasada eliminowania możliwości błędnego montażu: konstruktor powinien tak zaprojektować wyrób, aby jego elementy składowe nie zostały 
zmontowane w nieprawidłowy sposób. Podczas projektowania należy liczyć się $\mathrm{z}$ niedbalstwem pracowników, gdzie nie wystarczą odpowiednie ostrzeżenia na instrukcjach montażowych. W przypadku np. pokrywy łożyska, gdzie dwie składowe części są ustalone względem siebie za pomocą dwóch kołków to dobrym rozwiązaniem jest rozmieścić je niesymetrycznie względem osi sworzni mocujących.

\section{Przygotowanie konstrukcyjne wyrobów}

Etap konstrukcyjnego przygotowania produkcji polega na określeniu przedmiotu planowanej produkcji poprzez charakteryzację wszystkich cech produktu oraz zasad jego poprawnej eksploatacji $[4,14]$. Ta faza projektowania jest bardzo ważna, skomplikowana i głównie zależy od kreatywności oraz inwencji konstruktorów. Jej istotność wynika stąd, że jej początek zaczyna się od określenia koncepcji produktu, a kończy się kiedy projekt konstrukcji wyrobu jest zatwierdzony do produkcji, jak również skutki podjętych decyzji w tej fazie wpływają działania pozostałych faz procesu produkcyjnego, aż do momentu likwidacji produkcji.

W procesie konstrukcyjnego przygotowania produkcji należy brać pod uwage następujące, najważniejsze czynniki [14]:

- typ konstruowanego produktu - określenie czy produkt jest: nowy, ale rozpowszechniony na rynku, alternatywny, ulepszony,

- złożoność wyrobu,

- poziom skomplikowania wyrobu,

- potencjalna wartość wyrobu,

- zakres nowoczesnych rozwiązań oraz ich możliwość industrialnego wykorzystania,

- wielopoziomowość z wykorzystaniem produktu bazowego.

Zastosowanie tradycyjnych metod zarządzania oraz klasycznych rozwiązań w odniesieniu do produkcji jednostkowej jest niemożliwe ze względu na [13]:

- wysoką różnorodność oraz indywidualizacja produktów,

- zmienność zapotrzebowania materiałowego,

- zróżnicowane operacje technologiczne,

- zróżnicowane czasy jednostkowe,

- częste przezbrojenia,

- brak powtarzalności.

\section{Przykład analizy technologiczności}

Biorąc pod uwagę założenie wynikające $\mathrm{z}$ podanej wcześniej definicji technologiczności w przykładzie przyjęto, że jeżeli dane rozwiązanie konstrukcyjne charakteryzuje się niższymi kosztami i krótszym czasem realizacji procesu wytwarzania można przyjąć, że jest rozwiązaniem o lepszej technologiczności. W przeprowadzonych analizach przeprowadzono proces generowania różnych 
wariantów struktury montażowej wybranego produktu - urządzenia rekreacji zimowej. Generowanie wariantów wykonano w oparciu o decyzje eksperckie. Takie podejście wynikało z powodu realizacji procesu wytwarzania w warunkach produkcji jednostkowej i braku bazy wiedzy o wariantach struktury montażowej badanego wyrobu. Na podstawie wygenerowanych wariantów określono koszty wytworzenia i czasy realizacji wytworzenia. Wykorzystując analizę Paretto wyodrębniono warianty o najwyższym stopniu technologiczności czyli o najniższych kosztach i najkrótszym czasie realizacji wytworzenia.

W szczególności przykład dotyczy kosztów i czasów wykonania - karuzeli obrotowej (rys. 3). Produkcja, jak już wspomniano, odbywa się w sposób jednostkowy a sam produkt jest personalizowany dokładnie pod wymagania klienta. Klient zaangażowany jest w proces produkcyjny od najwcześniejszego etapu. Jego zadaniem jest określenie między innymi takich parametrów jak rodzaj zasilania urządzenia, szata graficzna oraz inne dodatkowe opcje. Na rys. 2 zaprezentowano schemat podziału karuzeli obrotowej na elementy, podzespoły i zespoły.

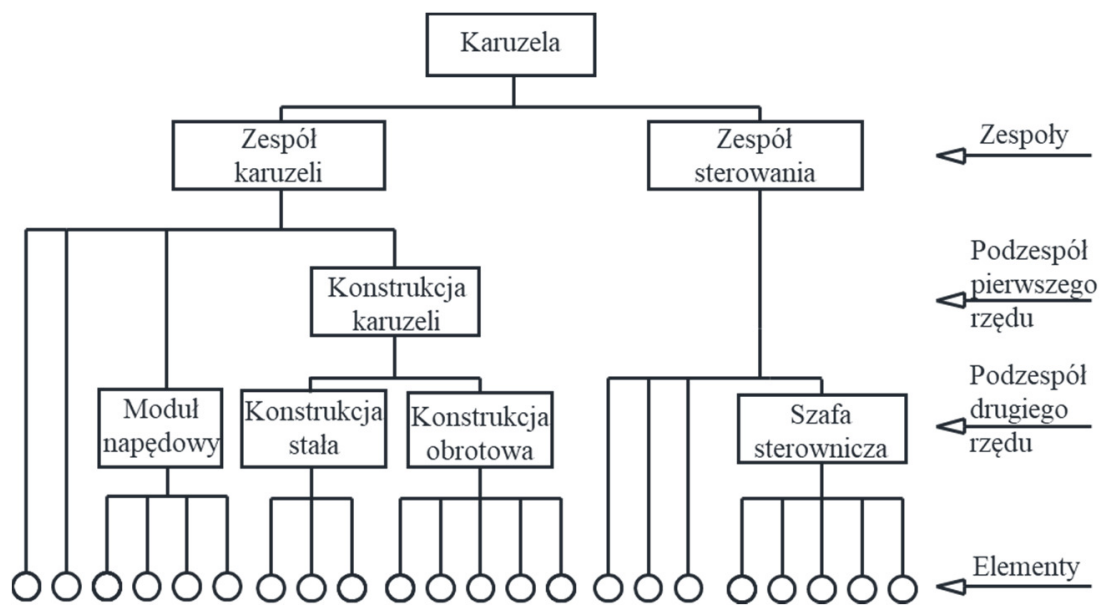

Rysunek 2. Schemat podziału karuzeli obrotowej (źródto: opracowanie własne)

Producentów tego typu urządzeń na rynku jest niewielu. Duża część inwestorów zdaje sobie sprawę, że głównym celem zakupu tego typu urządzeń nie jest zarobienie pieniędzy z tytułu jego użytkowania przez konsumentów. Wykorzystywane jest bardziej jako dodatkowa atrakcja pozwalająca na ściągnięcie większej liczby turystów na swoje inne atrakcje (noclegi w hotelach, stoki narciarskie, obiekty gastronomiczne, itp.). Aby oferowane urządzenie spełniło oczekiwania klienta należy wyprodukować je w ściśle określonym czasie oraz koszcie, który będzie niższy od konkurencji. Nie należy również zapomnieć, że wyrób finalny powinien charakteryzować się wysoką jakością, porównywalną, a nawet lepszą niż produkt konkurencyjny. Klient powinien mieć pewność, że kupuje wyrób wysokiej klasy spersonalizowany dokładnie pod swoje wymagania (logo na urządzeniu, szata graficzna dopasowana do otoczenia, itp.).

Obok urządzenia zamontowana jest szafa sterownicza napędu. Ze względu na bezpośredni kontakt $\mathrm{z}$ warunkami atmosferycznymi (deszcz, śnieg) konstrukcja powinna być zabezpieczona przed korozją (cynkowanie ogniowe, cynkowanie galwaniczne, malowanie). 


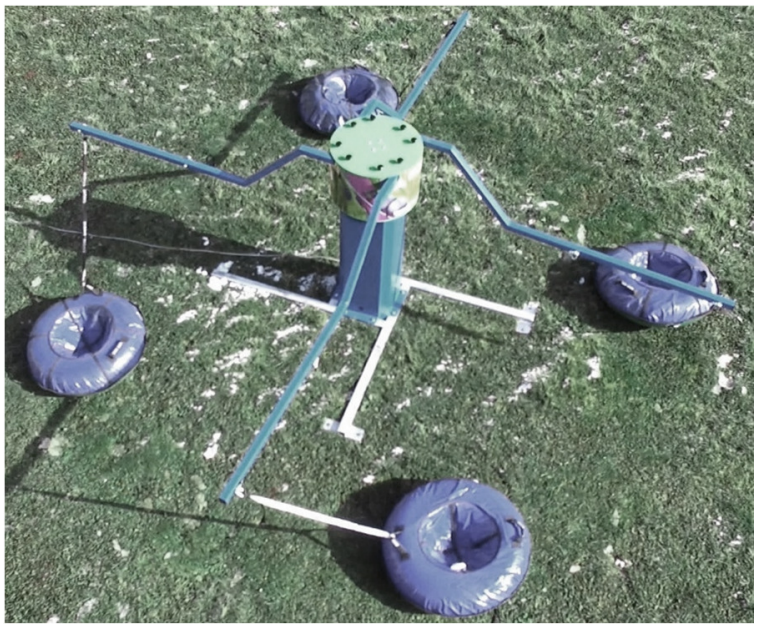

Rysunek 3. Karuzela obrotowa - urzadzenie rekreacyjne

W analizie zostaną przedstawione alternatywne procesy technologiczne charakteryzujące się różnymi czasami oraz kosztami wykonania. Za proces najbardziej technologiczny zostanie uznany ten, za pomocą, którego możliwe stanie się wykonanie urządzenia o akceptowalnych parametrach jakościowych przy zachowaniu założonego kosztu oraz czasu granicznego.

$\mathrm{Na}$ etapie koncypowania nad projektem projektant (konstruktor, technolog i organizator produkcji w jednej osobie) z wykorzystaniem wiedzy eksperckiej o możliwościach technicznych firmy oraz kooperantów określił kilka możliwości rozwiązań konstrukcyjnych danego podzespołu, które przedstawiono poniżej (tab. 1). Po wykonanej analizie rynku oszacowano wartość kosztu oraz czasu granicznego, których zachowanie będzie kluczowe, aby dany wyrób stał się atrakcyjny cenowo względem produktów konkurencji (tab. 2).

Tabela 1. Możliwe rozwiązania konstrukcyjne

\begin{tabular}{|c|c|c|c|c|}
\hline & \multicolumn{4}{|c|}{ Rozwiązanie konstrukcyjne } \\
\cline { 2 - 5 } Materiał & Stal & II & III & IV \\
\hline $\begin{array}{c}\text { Stal } \\
\text { łączenón }\end{array}$ & Spawania & Skręcanie & $\begin{array}{c}\text { Spawanie } \\
\text { + skręcanie }\end{array}$ & Kątownik \\
\hline $\begin{array}{c}\text { Półfabrykat } \\
\text { modułu } \\
\text { stałego }\end{array}$ & Blacha gięta & $\begin{array}{c}\text { Kształtownik } \\
\text { zamknięty }\end{array}$ & $\begin{array}{c}\text { Rura } \\
\text { bezszwowa }\end{array}$ & Silnik \\
Napęd & $\begin{array}{c}\text { Motoreduktor } \\
\text { walcowy }\end{array}$ & $\begin{array}{c}\text { Silnik } \\
\text { elektryczny z } \\
\text { przekładnią } \\
\text { pasową }\end{array}$ & $\begin{array}{c}\text { elektryczny z } \\
\text { przekładnią } \\
\text { łańcuchową }\end{array}$ & \\
\hline $\begin{array}{c}\text { Przeniesienie } \\
\text { napędu }\end{array}$ & Piasta & $\begin{array}{c}\text { Tuleja } \\
\text { rozprężna }\end{array}$ & & \\
\hline
\end{tabular}


Tabela 2. Wielkości graniczne

\begin{tabular}{|l|c|l|}
\hline \multicolumn{1}{|c|}{ Parametr } & Wartość & \multicolumn{1}{c|}{ jm } \\
\hline Koszt & 20000 & PLN \\
\hline Czas produkcji & 70 & godzin \\
\hline
\end{tabular}

Z przedstawionych powyżej rozwiązań konstrukcyjnych poszczególnych podzespołów uzyskano 18 alternatywnych metod wykonania kompletnego urządzenia o zróżnicowany koszcie oraz czasie produkcji. Taka ilość uzyskanych alternatywnych procesów możliwa jest dzięki dostępowi do dużej ilości maszyn przez przedsiębiorstwo oraz szerokie układy kooperacyjne. Poniżej zostały przedstawione uzyskane szacunkowe wartości kosztu i czasu dla każdego z wariantów przy uwzględnieniu cech konstrukcyjnych tych wariantów i wartości granicznych (tab.3).

Tabela 3. Uzyskane wielkości dla alternatywnych procesów produkcyjnych.

\begin{tabular}{|c|c|c|}
\hline $\begin{array}{c}\text { Rozwiązanie } \\
\text { Konstrukcyjne }\end{array}$ & Koszt [PLN] & Czas [h] \\
\hline 1. & $19500,00 \mathrm{zł}$ & 68 \\
\hline 2. & $21600,00 \mathrm{zł}$ & 82 \\
\hline 3. & $16650,00 \mathrm{zł}$ & 65 \\
\hline 4. & $18750,00 \mathrm{zł}$ & 72 \\
\hline 5. & $19900,00 \mathrm{zł}$ & 78 \\
\hline 6. & $22100,00 \mathrm{zł}$ & 85 \\
\hline 7. & $26500,00 \mathrm{zł}$ & 80 \\
\hline 8. & $16200,00 \mathrm{zł}$ & 60 \\
\hline 9. & $17800,00 \mathrm{zł}$ & 67 \\
\hline 10. & $18700,00 \mathrm{zł}$ & 76 \\
\hline 11. & $21300,00 \mathrm{zł}$ & 82 \\
\hline 12. & $22500,00 \mathrm{zł}$ & 86 \\
\hline 13. & $19700,00 \mathrm{zł}$ & 76 \\
\hline 14. & $28600,00 \mathrm{zł}$ & 86 \\
\hline 15. & $20500,00 \mathrm{zł}$ & 78 \\
\hline 16. & $15200,00 \mathrm{zł}$ & 72 \\
\hline 17. & $15100,00 \mathrm{zł}$ & 64 \\
\hline 18. & $19500,00 \mathrm{zł}$ & 57 \\
\hline & & \\
\hline
\end{tabular}

Kolejnym krokiem jest analiza Pareto oraz wybór wariantu optymalnego w sensie Pareto. Wyniki tej analizy zobrazowano na wykresie (rys.4). 


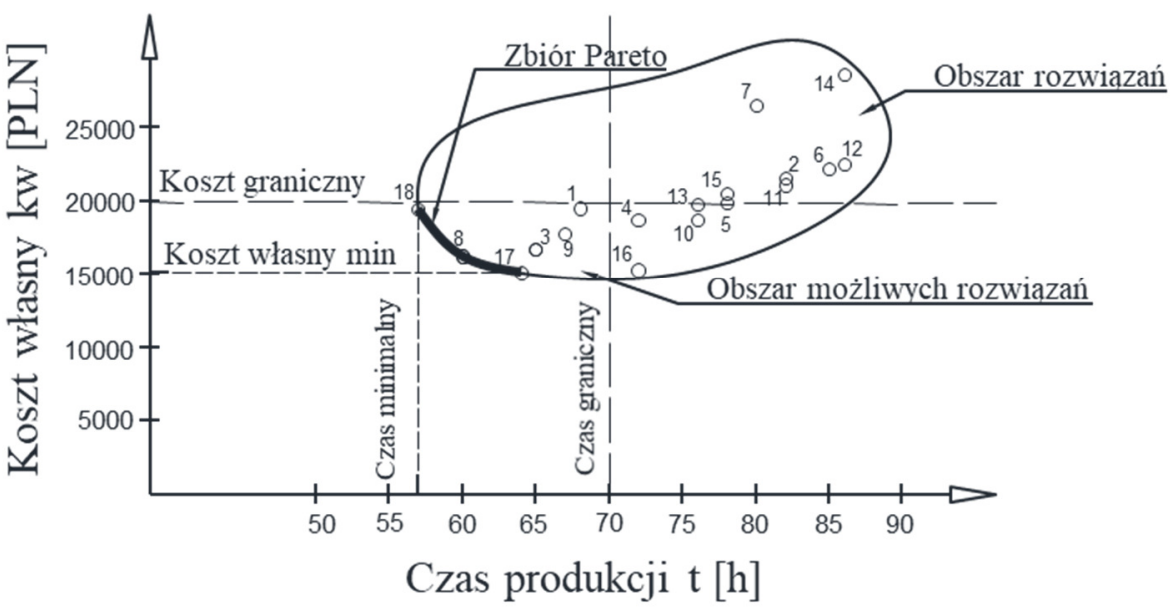

Rysunek 4. Zbiór Pareto dla minimalizacji

Z przedstawionych alternatywnych procesów produkcyjnych wyodrębniono obszar możliwych rozwiązań oraz zbiór Pareto. W obszarze możliwych rozwiązań znajdują się takie rozwiązania jak: $18,8,17,3,9,1$. Pozostałe rozwiązania nie spełniają obu wielkości granicznych. Minimalny czas produkcji to czas realizacji procesu $\mathrm{nr} 18$ i wynosi 57 godzin, natomiast minimalny koszt przypada na proces $\mathrm{nr} 17$ i wynosi 15100 PLN. Rozwiązania te wraz z procesem nr 8 należą do zbioru Pareto, a więc nie mogą one być poprawione względem czasu oraz kosztu ponieważ poprawa jednego kryterium skutkowała by pogorszeniem z uwagi na drugie. Takie rozwiązanie określane jest optymalnym w sensie Pareto.

\section{Wnioski}

Podczas projektowania nowych wyrobów dużą uwagę należy poświęcić kwestii związanej $\mathrm{z}$ doskonaleniem technologiczności $\mathrm{z}$ punktu widzenia zaopatrzenia, kooperacji, obróbki montażu oraz zbytu. Proces kooperacji w krajowych warunkach przemysłu ma znaczny wpływ na realizację produkcji.

Uzyskanie wielu alternatywnych procesów produkcyjnych wymaga dużego doświadczenia oraz zdolności kadry pracowniczej. Określenie szerokiego pola możliwych rozwiązań pozwala na minimalizację kosztów własnych projektu oraz ograniczenie czasu realizacji co w konsekwencji może polepszyć konkurencyjność oferowanych wyrobów.

Problematyka związana z procesem przygotowania produkcji jest złożona i wymaga poświęcenia dużej uwagi. Proces produkcyjny powinien charakteryzować się odpornością na wystąpienie zakłóceń, ponieważ wystąpienie pomyłki może być źródłem powstania nieprzewidzianych kosztów, które będzie musiało ponieść przedsiębiorstwo w celu jej eliminacji. 


\section{LITERATURA}

1. FELD M., Podstawy projektowania procesów technologicznych typowych części maszyn, Wydawnictwo Naukowo - Techniczne, Warszawa 2000.

2. GRABOWSKA M., NAJLEPSZY Z., Analiza możliwości skrócenia czasu montażu narzędzi chirurgicznych $\mathrm{z}$ punktu widzenia optymalizacji kosztów produkcji, Innowacje w zarządzaniu i inżynierii produkcji T. 1, Oficyna Wydawnicza Polskiego Towarzystwa Zarządzania Produkcją, Opole 2016, s. $768-778$.

3. GRZECHCA W., Balansowanie linii montażowej z uwzględnieniem kosztów, Wydawnictwo Pomiary Automatyka Kontrola vol. 53, nr 8/2007, s. 10-12, Warszawa 2007.

4. LIWOWSKI B., KOZŁOWSKI R., Podstawowe zagadnienia zarządzania produkcją, Oficyna Ekonomiczna, Kraków 2017.

5. MATUSZEK J., SENETA T., Algorytmizacja procesu wdrażania nowego produktu w warunkach wielkoseryjnej produkcji, Mechanik nr 7/2016.

6. MATUSZEK J., SENETA T., DULINA L., BIGOSOVA E.: Manufacturability assessment of the product assembly processes design in the automotive industry. Nr 6.2020, s. 3-11.

7. MATUSZEK, J., \& SENETA, T. (2019). Assessment of design manufacturability in assembly processes by modified Boothroyd \& Dewhurst DFA method. Mechanik, 92(7), s. 448-450.

8. Matuszek, J., Seneta, T., \& Moczała, A. (2018). of article: Ocena technologiczności konstrukcji w procesach montażu według zmodyfikowanej metody Lucas DFA, Evalua. Mechanik, 91(7), s. 532-534.

9. MATUSZEK, J., SENETA, T., \& MOCZAŁA, A. (2019). Fuzzy assessment of manufacturability design for machining. Applied Computer Science, 15.2020.

10. ORŁOW P. I., Zasady konstruowania w budowie maszyn, Wydawnictwo Naukowo - Techniczne, Warszawa 1971.

11. Praca zbiorowa. 1995. Advancet Product Quality Planning (APQP) and Control Plan. Reference Manual. AAIG - Chrysler Corporation, Ford Corporation, General Motors Corporation. Adare Carvin., Unit 1, Trade Link, Western Ave, West Thurrock, Grays, Essex England, (norma branżowa).

12. SKARBIŃSKI M., SKARBIŃSKI J., Technologiczność konstrukcji maszyn, Wydawnictwo Naukowo - Techniczne, Warszawa 1982.

13. SKOWRON A., Wybrane zagadnienia badania cyklu realizacji zamówienia klienta w produkcji jednostkowej, Zeszyty Naukowe Politechniki Śląskiej, 2014.

14. SZATKOWSKI K., Przygotowanie produkcji, Wydawnictwo Naukowe PWN, Warszawa 2008. 